\title{
Genetic Diversity Among Geminiviruses Associated with the Weed Species Sida spp., Macroptilium lathyroides, and Wissadula amplissima from Jamaica
}

\author{
Marcia E. Roye and Wayne A. McLaughlin, Biotechnology Center and the Department of Biochemistry, Univer- \\ sity of the West Indies, Mona, Kingston, Jamaica, and Medhat K. Nakhla and Douglas P. Maxwell, Department of \\ Plant Pathology, University of Wisconsin, Madison 53706
}

\begin{abstract}
Roye, M. E., McLaughlin, W. A., Nakhla, M. K., and Maxwell, D. P. 1997. Genetic diversity among geminiviruses associated with the weed species Sida spp., Macroptilium lathyroides, and Wissadula amplissima from Jamaica. Plant Dis. 81:1251-1258.

Genetic diversity among geminiviruses associated with three common weeds in Jamaica was studied using digoxigenin-labeled geminiviral DNA probes, polymerase chain reaction with degenerate primers for DNA-A and DNA-B, nucleic acid sequencing, and derived amino acid sequences. Geminiviruses with bipartite genomes were found in Sida spp., Macroptilium lathyroides, and Wissadula amplissima. The geminiviruses detected in Sida spp. and M. lathyroides were nearly identical and were both designated Sida golden mosaic geminivirus (SidGMV-JA), whereas the geminivirus in W. amplissima was sufficiently different to be designated Wissadula golden mosaic geminivirus (WGMV). Nucleotide sequence comparisons of the common regions and the N-terminal regions of the AC1 (rep) and AV1 ORFs, together with the derived amino acid sequence comparisons of the N-terminal parts of BC1 and BV1 ORFs were used to determine their similarities to other geminiviruses. SidGMV-JA was most similar to potato yellow mosaic geminivirus (PYMV). We propose that these two geminiviruses (SidGMV-JA and PYMV) define a new geminivirus cluster, the potato yellow mosaic virus (PYMV) cluster. WGMV was most similar to members of the Abutilon mosaic virus cluster but is not likely to be included in the Abutilon phylogenetic group because of the divergent sequence of the common region. These results indicate that geminiviruses infecting some weeds in Jamaica are distinct from crop-infecting geminiviruses in Jamaica and define a new geminivirus cluster.
\end{abstract}

Weeds are important reservoirs for some plant viruses $(2,5)$; however, it is not known if weeds are a significant source of inoculum for any important crop-infecting whitefly-transmitted geminiviruses. During the last decade, total crop failures were associated with geminivirus infection of tomatoes, peppers, beans, and cucurbits in the Western Hemisphere (4; D. P. Maxwell, unpublished data). The introduction into the Western Hemisphere of the B biotype of the whitefly, Bemisia tabaci, is partially responsible for these increased losses (4).

The first report of whitefly-transmitted viruses in Jamaica was made in 1975 by Pierre, who reported golden mosaic symptoms on beans and suggested that this disease was the major constraint on bean production on the island (24). This whitefly-transmitted virus was later characterized as bean golden mosaic geminivirus type II, a bipartite geminivirus, and was found in Central America and other

Corresponding author: M. E. Roye

Email: mroye@uwimona.edu.jm

Accepted for publication 17 July 1997.

Publication no. D-1997-0828-02R

(C) 1997 The American Phytopathological Society islands of the Caribbean region (20). Recently, the monopartite, whitefly-transmitted tomato yellow leaf curl geminivirus from the Eastern Hemisphere was reported in the Dominican Republic (22) and Jamaica (19; M. E. Wernecke, M. E. Roye, M. K. Nakhla, D. P. Maxwell, and W. A. McLaughlin, unpublished). Additionally, a bipartite geminivirus was found infecting both tomatoes and peppers in Jamaica (28).

Preliminary reports indicate that the primary geminiviruses infecting weeds are not the same ones that infect crops $(11,25,27)$, although it has been speculated that a number of common weeds may serve as alternate hosts for crop-infecting geminiviruses. Only limited work has been done to characterize the geminiviruses associated with weeds at the molecular level, whereas several geminiviruses infecting vegetable crops in the Western Hemisphere have been so characterized (see review by Green and Kallo [13]). Rhynchosia mosaic geminivirus, whose natural host is Rhynchosia minima, was transmitted to beans, in which it causes typical mosaic, dwarfing, and leaf distortion (9). A Sida sp. believed to be an alternate host for bean dwarf mosaic geminivirus (BDMV) proved to be susceptible to this virus (21). Therefore, it is important to determine if weeds are alternate hosts for crop-infecting geminiviruses. These results may significantly affect the development of strategies for managing the spread of these geminiviruses. In this paper, we report the partial molecular characterization of geminiviruses associated with Sida spp., Macroptilium lathyroides, and Wissadula amplissima from Jamaica to determine if these weeds could be a possible reservoir for crop-infecting geminiviruses.

\section{MATERIALS AND METHODS}

Preparation of digoxigenin-labeled geminiviral DNA probes by polymerase chain reaction (PCR). A 1.1-kb DNA-A fragment amplified by PCR from BGMVJA type II from Jamaica (GenBank no. L34269) was used as the template for synthesizing a geminiviral DNA probe (PBGJA) used at low stringency hybridization (11,20). Digoxigenin-11-dUTP (Dig-11-dUTP) (Boehringer Mannheim Corp., Indianapolis, IN) was incorporated into the DNA during PCR (26) with 30 cycles of $1 \mathrm{~min}$ at $94^{\circ} \mathrm{C}, 2 \mathrm{~min}$ at $55^{\circ} \mathrm{C}$, and $2 \mathrm{~min}$ at $72^{\circ} \mathrm{C}$ and a reaction mixture with concentrations of $0.2 \mu \mathrm{M}$ for each degenerate primer of the pair PAC1v1978 (viral sense polarity)/PAV1c496 (complementary sense polarity) (26), $1 \mathrm{mM}$ for each of the nucleotides dATP, dCTP, and dGTP; $0.65 \mathrm{mM}$ dTTP; $0.35 \mathrm{mM}$ Dig-11dUTP; 200 ng of target DNA; and 1.2 units of DNA Taq polymerase (Promega Corp., Madison, WI) in $50 \mu \mathrm{l}$. The presence of the expected molecular weight PCR product was confirmed by agarose gel electrophoresis (29). Digoxigenin-labeled probes from DNA-A inserts of recombinant plasmids containing PCR-amplified fragments of viruses from infected Sida sp. (pSGJA1) and $W$. amplissima (pWGJA2) were similarly prepared. These probes were hybridized at high stringency (11) to DNA extracted from the original infected plants to confirm that the cloned viral fragments were identical to the geminiviral DNA from the original source plants used for cloning.

Detection of geminiviral nucleic acid by dot blot hybridization. Sida spp., $M$. lathyroides, and $W$. amplissima with golden mosaic symptoms were collected from five parishes in Jamaica (Table 1). Viral DNA was extracted from either fresh or oven-dried $\left(60^{\circ} \mathrm{C}\right)$ leaf samples by a modified Dellaporta extraction method and dissolved in distilled water $(6,26)$. Each DNA extract was spotted onto either a 
Zetabind nylon membrane (CUNO, Inc., Meriden, CT) or a positively charged nylon membrane (Boehringer Mannheim) and baked at $80^{\circ} \mathrm{C}$ under vacuum for $2 \mathrm{~h}$. Prehybridization, hybridization, and immunological detection were completed using the Genius 2 DNA Labeling and Detection Kit (Boehringer Mannheim) according to the manufacturer's instructions. Membranes were prehybridized ( 1 to $4 \mathrm{~h}$ ) and hybridized ( 8 to $12 \mathrm{~h}$ ) at either low stringency $\left(42^{\circ} \mathrm{C}\right.$ with $50 \%$ formamide $)$ or high stringency $\left(68^{\circ} \mathrm{C}\right.$ without formamide) in $5 \times \mathrm{SSC}(1 \times \mathrm{SSC}=0.15 \mathrm{M} \mathrm{NaCl}, 15 \mathrm{mM}$ sodium citrate, $\mathrm{pH} 7$ ) containing $0.1 \% \mathrm{~N}$ lauroylsarcosine, $0.02 \%$ sodium dodecyl sulfate (SDS), and 2 to $5 \%$ blocking reagent (Boehringer Mannheim). Membranes were washed twice at room temperature with $2 \times$ SSC containing $0.1 \%$ SDS and twice at either $42^{\circ} \mathrm{C}$ (low stringency) or $68^{\circ} \mathrm{C}$ (high stringency) with $0.1 \times$ SSC containing $0.1 \%$ SDS. After block binding of an antibody conjugate (Boehringer Mannheim) to the hybridized digoxigenin-labeled DNA, hy- bridization was detected by a purple color reaction initiated at alkaline $\mathrm{pH}$ by the addition of 5-bromo-4-chloro-3-indolyl phosphate and nitroblue tetrazolium.
Amplification of geminiviral DNA by PCR. Viral DNA was amplified using degenerate PCR primer pairs PAC1v1978/ PAV1c715 for DNA-A and PBC1v2039/

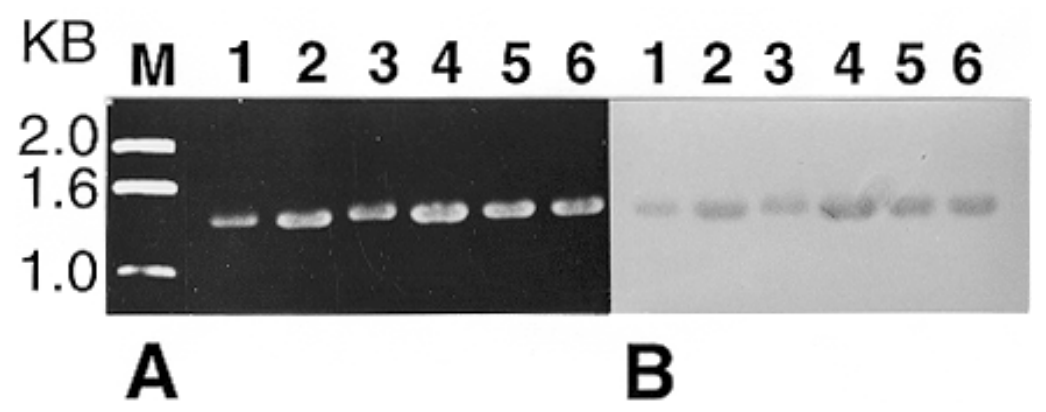

Fig. 1. Polymerase chain reaction (PCR)-amplified products for (A) DNA-A of geminiviruses from Wissadula amplissima, Macroptilium lathyroides, and Sida sp. and (B) Southern blot DNA hybridizations. (A) Amplification of 1.3-kb fragments with primer pair PAC1v1978/PAV1c715. A 3- $\mu 1$ aliquot of each PCR reaction mixture was analyzed in a $0.7 \%$ agarose gel. Left lane $=1-\mathrm{kb}$ ladder size marker. Plant samples are: W, W. amplissima sample 27, M, M. lathyroides sample 16, W, W. amplissima sample 30, M, M. lathyroides sample 19, S, Sida sp. sample 3, and S, Sida sp. sample 9 (Table 1). (B) Southern blot hybridization of the agarose gel in (A) (lanes in the same order). The blot was probed with the BGMV type II from Jamaica geminiviral DNA probe at low stringency.

Table 1. Geographical origin of weed samples in Jamaica used for detection of geminiviral DNA with DNA hybridization methods and polymerase chain reaction

\begin{tabular}{|c|c|c|c|c|c|c|c|c|}
\hline \multirow[b]{2}{*}{ Plant } & \multirow[b]{2}{*}{ Sample no. } & \multirow[b]{2}{*}{ Origin $^{a}$} & \multirow[b]{2}{*}{ Date collected } & \multirow[b]{2}{*}{ Symptoms ${ }^{b}$} & \multirow[b]{2}{*}{ Hyb I ${ }^{c}$} & \multicolumn{2}{|c|}{ PCR fragment size $(k b)$} & \multirow[b]{2}{*}{ Hyb II ${ }^{\mathrm{e}}$} \\
\hline & & & & & & DNA-A ${ }^{d}$ & DNA-B $^{d}$ & \\
\hline Sida sp. & 1 & Man & $3 / 93$ & + & + & 1.3 & 0.5 & + \\
\hline Sida sp. & 2 & Man & $5 / 93$ & + & - & ND & ND & ND \\
\hline Sida sp. & 3 & St. M & $5 / 93$ & + & + & 1.3 & 0.5 & + \\
\hline Sida sp. & 4 & St. M & $5 / 93$ & + & + & 1.3 & ND & + \\
\hline Sida sp. & 5 & St. T & $4 / 93$ & + & + & 1.3 & 0.5 & + \\
\hline Sida sp. & 6 & St. E & $6 / 93$ & + & + & 1.3 & 0.5 & + \\
\hline Sida sp. & 7 & $\mathrm{Cla}$ & $6 / 93$ & - & - & - & - & - \\
\hline Sida sp. & 8 & St. M & $4 / 93$ & + & + & 1.3 & 0.5 & + \\
\hline S. urens & 9 & St. E & $6 / 93$ & + & + & 1.3 & 0.5 & + \\
\hline S. urens & 10 & Man & $6 / 93$ & + & + & 1.3 & 0.5 & + \\
\hline S. urens & 11 & St. E & $3 / 93$ & + & + & 1.3 & 0.5 & + \\
\hline S. acuta & 12 & St. A & $3 / 93$ & + & - & ND & ND & ND \\
\hline S. acuta & 13 & Man & $3 / 93$ & + & - & ND & ND & ND \\
\hline S. acuta & 14 & Man & $3 / 93$ & + & - & ND & ND & ND \\
\hline Macroptilium lathyroides & 15 & St. A & $3 / 93$ & + & + & 1.3 & 0.5 & + \\
\hline M. lathyroides & 16 & St. A & $3 / 93$ & + & + & 1.3 & 0.5 & + \\
\hline M. lathyroides & 17 & St. $\mathrm{T}$ & $4 / 93$ & + & + & 1.3 & 0.55 & - \\
\hline M. lathyroides & 18 & St. T & $5 / 93$ & + & + & 1.3 & $0.5 / 0.55$ & + \\
\hline M. lathyroides & 19 & St. M & $11 / 94$ & + & + & 1.3 & 0.5 & + \\
\hline M. lathyroides & 20 & St. M & $4 / 94$ & + & + & 1.3 & 0.55 & - \\
\hline M. lathyroides & 21 & St. E & $3 / 93$ & + & + & 1.3 & 0.55 & - \\
\hline M. lathyroides & 22 & St. E & $3 / 93$ & + & + & 1.3 & 0.55 & - \\
\hline M. lathyroides & 23 & St. E & $3 / 93$ & + & + & 1.3 & 0.5 & + \\
\hline M. lathyroides & 24 & Man & $3 / 93$ & + & + & 1.3 & 0.5 & + \\
\hline M. lathyroides & 25 & St. A & $10 / 94$ & - & - & - & - & - \\
\hline Wissadula amplissima & 26 & St. A & $10 / 94$ & + & + & 1.3 & 0.5 & + \\
\hline W. amplissima & 27 & St. E & 3/94 & + & + & 1.3 & 0.5 & + \\
\hline W. amplissima & 28 & St. E & $4 / 93$ & + & + & 1.3 & 0.5 & + \\
\hline W. amplissima & 29 & Man & $4 / 93$ & + & + & 1.3 & 0.5 & + \\
\hline W. amplissima & 30 & St. T & $6 / 93$ & + & + & 1.3 & 0.5 & + \\
\hline W. amplissima & 31 & St. $T$ & $3 / 93$ & + & + & 1.3 & 0.5 & + \\
\hline W. amplissima & 32 & $\mathrm{Cla}$ & $3 / 93$ & + & - & ND & ND & ND \\
\hline W. amplissima & 33 & St. E & $3 / 93$ & - & - & - & - & - \\
\hline
\end{tabular}

${ }^{a}$ Samples were collected in the parishes of: Man = Manchester, St. M = St. Mary, St. T= St. Thomas, St. E = St. Elizabeth, Cla = Clarendon, and St. A= St. Ann.

b Symptoms: + = golden mosaic, $-=$ no symptoms.

${ }^{\mathrm{c}}$ Hyb I = hybridization at low stringency with digoxigenin-labeled BGMV-JA type II geminiviral DNA probe (PBGJA). + = hybridization signal detected, $-=$ no hybridization signal detected, $\mathrm{ND}=$ not done.

${ }^{\mathrm{d}}$ DNA-A = PCR-amplified DNA fragment (primers PAC1v1978/PAV1c715), DNA-B = PCR-amplified DNA fragment (primers PBC1v2039/PCRc2). Expected sizes are $1.3 \mathrm{~kb}$ for DNA-B and between 0.35 and $0.65 \mathrm{~kb}$ for DNA-B (26).

${ }^{\mathrm{e}} \mathrm{Hyb}$ II $=$ hybridization at high stringency with viral insert from pSGJA1 (samples 1 to 25) and pWGJA1 (samples 26 to 33). + = hybridization signal detected, $-=$ no hybridization signal detected, $\mathrm{ND}=$ not done. 
PCRc2 or PBC1v2039/PBV1c800 (5'ACGACTTGCAGTTVACMGTCCCTTT GAAACG-3') for DNA-B (26; M. B. Bett and D. P. Maxwell, unpublished data). PCR reaction conditions were as described by Rojas et al. (26). Amplified DNA fragments were electrophoresed in $0.7 \%$ agarose (FMC, Rockland, $\mathrm{MN}$ ) minigels in $0.5 \times$ TBE buffer (45 $\mathrm{mM}$ tris-borate, 1 mM EDTA, pH 8.0), visualized with UV light after staining with ethidium bromide, and photographed.

Preparation of $\left[{ }^{32} \mathbf{P}\right]$-labeled geminiviral DNA probe and Southern blot hybridization analysis. A $\left[{ }^{32} \mathrm{P}\right]$-labeled geminiviral DNA probe for Southern blot hybridization (29) was used to confirm the geminiviral origin of PCR-amplified DNA fragments. A 0.6-kb fragment of DNA-B of BGMV-GA type II from Guatemala was amplified by PCR using primer pair PBC1v2039/PCRc2 (26). The 0.6-kb fragment was then labeled with $\left[{ }^{32} \mathrm{P}\right] \mathrm{dCTP}$ using a random priming kit (Bethesda Research Laboratories, Gaithersburg, MD). PCR with this same primer pair generated 0.5 - and/or $0.55-\mathrm{kb}$ fragments from DNA extracted from the weeds in this study. These fragments were purified by agarose gel electrophoresis and then transferred to a Zetabind nylon membrane for hybridization with the probe. Prehybridization and hybridization conditions at low stringency were as described by Gilbertson et al. (11).

Cloning of PCR-amplified DNA fragments. PCR-amplified products were digested with PstI (Promega Corp.), extracted twice with an equal volume of phenol:chloroform:isoamyl alcohol (25:24:1) and once with chloroform:isoamyl alcohol (24:1), precipitated with 2.5 volumes of absolute ethanol, washed twice with $70 \%$ ethanol, and dried in a Speed Vac dryer (Savant Instruments Inc., Farmingdale, NJ). The purified PCR products were then ligated into PstI-digested pBluescript II $\mathrm{KS}+$ vector (Stratagene, La Jolla, CA) and used to transform Escherichia coli strain XL1-Blue (Stratagene). Bacterial colonies with recombinant plasmids (beta-galactosidase negative) were selected for further characterization (29).

Nucleotide sequencing and analysis. DNA was sequenced, using $\left[{ }^{35} \mathrm{~S}\right]$-dATP, with Sequenase version 2 according to the manufacturer's instructions (United States Biochemical, Cleveland, $\mathrm{OH}$ ) and analyzed using the software of the Genetics Computer Group, Version 7, Madison, WI. Relationships among geminiviruses were examined by comparing nucleotide sequences using the GAP program of this software with a gap weight of 5 and a gap weight length of 0.3 . Phylogenetic analyses were done with the computer program Phylogenetic Analysis Using Parsimony version 3.1 (PAUP) developed by D. L. Swofford (Illinois Natural History Survey, Champaign, IL). Optimum trees were obtained by the Heuristic method with the branch swapping options. One hundred bootstrap replications were performed for each data set to assign branch strengths to topological elements. Geminiviruses were assigned to a cluster if bootstrap-replication analysis placed them in the same branch more than $50 \%$ of the time. Searches of the sequences in GenBank for similar viruses were completed with the BLAST program (http://www.ncbi.nlm. nih.gov/BLAST).

\section{RESULTS AND DISCUSSION}

Detection of geminiviral DNA in fieldcollected weed samples, with a digoxigenin-labeled geminiviral DNA probe. The geminiviral DNA probe from BGMVJA DNA-A (PBGJA), labeled with digoxigenin, hybridized at low stringency to DNA extracts of 25 of the 30 weed samples with golden mosaic symptoms: 9 Sida spp., $10 \mathrm{M}$. lathyroides, and $6 \mathrm{~W}$. amplissima. The probe did not hybridize with DNA from three symptomless plants: a
Sida sp. (sample 7), an M. lathyroides (sample 25), and a W. amplissima (sample 33). Those samples that had golden mosaic symptoms and did not hybridize with the probe included one Sida sp. plant (sample 2), three Sida acuta plants (samples 12 to 14), and a $W$. amplissima plant (sample 32) (Table 1). These results could be attributed to a titer of geminivirus below the level of detection or the presence of sufficient differences in the nucleotide sequence between the viral DNA and the probe to prevent hybridization at low stringency. Thus, geminiviruses are associated with these three weed genera.

Detection of geminiviruses by PCR. The PCR primer pair PAC1v1978/ PAV1c715 for DNA-A amplified the predicted 1.3-kb fragment from all plant samples that gave hybridization signals with PBGJA probe (Table 1). This fragment is expected to include $\mathrm{N}$-terminal parts of the rep and AV1 ( $c p)$ ORFs and the intergenic region, which contains the common region.

Table 2. Recombinant plasmids with geminiviral DNA inserts from polymerase chain reaction fragments from Sida sp., Macroptilium lathyroides, and Wissadula amplissima

\begin{tabular}{|c|c|c|c|c|c|}
\hline Host & Clone no. & $\begin{array}{c}\text { Insert size } \\
(\mathbf{k b})^{\mathrm{a}}\end{array}$ & $\begin{array}{l}\text { Genome } \\
\text { position }\end{array}$ & $\begin{array}{l}\text { Sequenced } \\
\text { region }(n t)^{b}\end{array}$ & GenBank no. \\
\hline $\begin{array}{l}\text { Sida sp. } \\
\text { (sample 3) }\end{array}$ & pSGJA1 & 1.4 & $\begin{array}{c}r e p \\
c p \\
\text { CR-A } \\
\text { BC1 } \\
\text { BV1 } \\
\text { CR-B }\end{array}$ & $\begin{array}{c}2,037-2,590 \\
469-716 \\
3-310 \\
2,035-2,273 \\
581-803 \\
53-186\end{array}$ & $\begin{array}{l}\text { U67926 } \\
\text { U68177 } \\
\text { U69601 } \\
\text { U69157 } \\
\text { U69158 } \\
\text { U69602 }\end{array}$ \\
\hline $\begin{array}{l}\text { M. lathyroides } \\
\text { (sample 19) }\end{array}$ & pMGJA1 & 1.3 & $\begin{array}{c}r e p \\
c p \\
\text { CR-A }\end{array}$ & $\begin{array}{c}1,960-2,228 \\
400-695 \\
4-184\end{array}$ & $\begin{array}{l}\text { U69159 } \\
\text { U69160 } \\
\text { U70386 }\end{array}$ \\
\hline $\begin{array}{l}\text { W. amplissima } \\
\text { (sample 27) }\end{array}$ & $\begin{array}{l}\text { pWGJA2 } \\
\text { pWGJA1 } \\
\text { pWGJB1 }\end{array}$ & $\begin{array}{l}0.55 \\
0.75 \\
\\
1.4\end{array}$ & $\begin{array}{c}\text { rep } \\
c p \\
\text { CR-A } \\
\text { BC1 } \\
\text { BV1 } \\
\text { CR-B }\end{array}$ & $\begin{array}{c}2,032-2,494 \\
370-707 \\
3-176 \\
2,029-2,199 \\
566-817 \\
3-181\end{array}$ & $\begin{array}{l}\text { U69281 } \\
\text { U69280 } \\
\text { U69603 } \\
\text { U69732 } \\
\text { U69733 } \\
\text { U69604 }\end{array}$ \\
\hline
\end{tabular}

${ }^{a}$ Inserts in recombinant plasmids are PCR fragments from primer pair PAC1v1978/PAV1c715 for DNA-A and PBC1v2039/PBV1c800 for DNA-B (26). PCR fragments were digested with PstI restriction endonuclease before cloning into PstI-digested pBluescript KS II (+).

${ }^{\mathrm{b}}$ Nucleotide positions represent the nucleotide numbers for the homologous regions of bean golden mosaic virus from Guatemala (7).

Table 3. Percent nucleotide sequence identities between the common region (CR) and the rep, $c p$, $\mathrm{BC} 1$, and BV1 (open reading frames) of geminiviruses form Wissadula amplissima and Sida sp. and the respective regions of seven other geminiviruses representing the major phylogenetic clusters for the Western Hemisphere geminiviruses

\begin{tabular}{lccccc}
\hline Geminiviruses $^{\mathbf{a}}$ & CR & rep & cp & BC1 & BV1 \\
\hline BGMV-GA & $76 / 65^{\text {b }}$ & $74 / 69$ & $74 / 80$ & $81 / 80$ & $67 / 67$ \\
ToMoV & $80 / 79$ & $78 / 74$ & $86 / 84$ & $86 / 85$ & $75 / 76$ \\
TGMV & $71 / 73$ & $76 / 76$ & $80 / 79$ & $79 / 80$ & $61 / 67$ \\
BGMV-BZ & $73 / 77$ & $68 / 74$ & $79 / 78$ & $76 / 76$ & $59 / 67$ \\
PYMV & $67 / 86$ & $75 / 85$ & $84 / 80$ & $84 / 86$ & $59 / 63$ \\
PHV & $63 / 61$ & $76 / 70$ & $74 / 76$ & $84 / 80$ & $61 / 66$ \\
SqLCV-E & $57 / 53$ & $60 / 55$ & $78 / 78$ & $77 / 76$ & $51 / 55$ \\
\hline
\end{tabular}

a BGMV-GA = bean golden mosaic virus from Guatemala type II; ToMoV = tomato mottle virus; TGMV = tomato golden mosaic virus; BGMV-BZ = BGMV from Brazil type I; PYMV = potato yellow mosaic virus; $\mathrm{PHV}=$ pepper huasteco virus; $\mathrm{SqLCV}-\mathrm{E}=$ squash leaf curl virus extended host range.

${ }^{\mathrm{b}}$ Numerator $=$ percent nucleotide identity for pairwise comparisons of sequence of the geminivirus from $W$. amplissima with the other geminiviruses. Denominator $=$ percent nucleotide identity for pairwise comparisons of the sequence of the geminivirus form Sida sp. with the other geminiviruses. 
The DNA-A probe (PBGJA) hybridized to all of the six selected 1.3-kb fragments: Sida sp. (samples 3 and 9), M. lathyroides (samples 16 and 19), and W. amplissima (samples 27 and 30). Therefore, these fragments are confirmed geminiviral DNA (Fig. 1). The DNA-B primer pair, PBL1v2039/PCRc2, designed to amplify a 0.3 - to $0.6-\mathrm{kb}$ fragment that includes the $\mathrm{N}$ terminal part of $\mathrm{BC} 1$ and the intergenic region between the common region and BC1 ORF, amplified 0.5- and/or 0.55-kb fragments from all three plant genera, which gave hybridization signals with the PBGJA probe. Two fragment sizes obtained with primer pair PBC1v2039/
PCRc2 for DNA-B indicated that $M$. lathyroides samples were probably infected with one or more geminiviruses, and that sample 18 had a mixed infection as indicated by the amplification of the two different PCR fragment sizes. A second DNA-B primer pair, PBC1v2039/PBV1c800, amplified the expected 1.4-kb fragment from one representative of each of the three plant genera (samples 3, 19, and 27). The 1.4-kb fragment is expected to include parts of the $\mathrm{BC} 1$ and BV1 ORFs, plus the intergenic region that includes the common region. The $\left[{ }^{32} \mathrm{P}\right]$-labeled geminiviral probe from DNA-B of BGMV-GA hybridized at low stringency to selected PCR-amplified 0.5- kb fragments from Sida sp. (sample 3), $M$. lathyroides (sample 19), and W. amplissima (sample 27). These results indicate that these three weeds are infected with bipartite geminiviruses.

The 1.3-kb DNA-A fragments generated by PCR were cloned, and recombinant plasmids were obtained for Sida sp. (sample 3, pSGJA1) and $M$. lathyroides (sample 19, pMGJA1). Two fragments $(0.75-$ and $0.55-\mathrm{kb})$ were obtained when the 1.3-kb PCR-amplified fragment from W. amplissima (sample 27) was digested with PstI for cloning. The 0.75- and 0.55$\mathrm{kb}$ fragments were cloned as pWGJA1 and pWGJA2, respectively. Similarly, the pu-

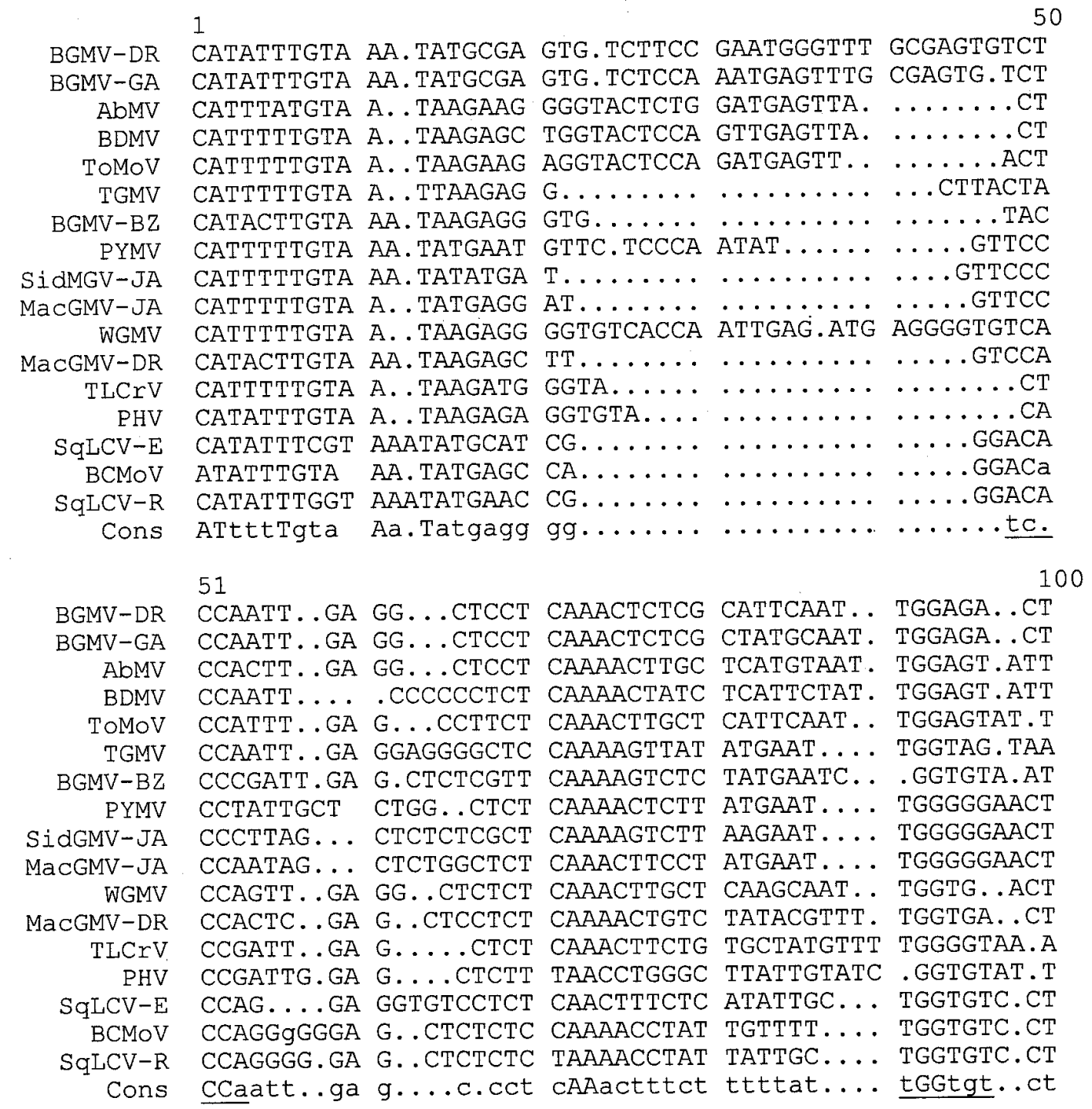

Fig. 2. continued on next page

Fig. 2. Nucleotide sequence alignment of the common region of 14 whitefly-transmitted geminiviruses from the Western Hemisphere. Sequences start at the initiation codon of the rep ORF (CAT, viral sense polarity) and terminate at the $3^{\prime}$ end of the stem-loop motif. The TATA box and stem-loop motif are marked with an asterisk (*). The repeat motifs downstream of the start of the common region, the repeat motifs upstream of the TATA box, and the conserved motif of the SqLCV cluster are all underlined. Gaps were inserted to provide maximum identity among the viruses. BGMV-GA = bean golden mosaic geminivirus from Guatemala (GenBank accession no. M91604), BGMV-DR = bean golden mosaic geminivirus from the Dominican Republic (L01635), AbMV = Abutilon mosaic geminivirus from West Indies (X15983), BDMV = bean dwarf mosaic virus from Colombia (M88179), ToMoV = tomato mottle virus from Florida, TGMV = tomato golden mosaic geminivirus from Brazil (K02029), BGMV-BZ = bean golden mosaic geminivirus from Brazil (M88686), PYMV = potato yellow mosaic geminivirus from Venezuela (D00940), SidGMV-JA = Sida golden mosaic virus from Jamaica (U69601), MacGMV-JA = Macroptilium golden mosaic virus from Jamaica isolate 2 (U73511), WGMV = Wissadula golden mosaic virus from Jamaica ((U69603), MacGMV-DR = Macroptilium golden mosaic virus from the Dominican Republic (25), TLCrV = tomato leaf crumple virus from Mexico (L34748), PHV = pepper huasteco virus from Mexico (X70418), SqLCV-E = squash leaf curl geminivirus from California, with extended host range (M38183), BCMoV = bean calico mosaic geminivirus (L22757), SqLCV-R = squash leaf curl geminivirus from California, with restricted host range (16), and Cons $=$ consensus sequence. 
tative DNA-B fragments generated by PCR with primer pair PBC1v2039/ PBV1c800 were cloned, and recombinant plasmids with 1.4-kb Pst I inserts were obtained for Sida sp. (sample 3, pSGJB1) and $W$. amplissima (sample 27, pWGJB1). Nucleotide sequences for the cloned parts of rep, $c p, \mathrm{BC} 1$, and $\mathrm{BV} 1 \mathrm{ORFs}$, and the common regions of DNA-A and DNA-B, were obtained for each insert from these recombinant plasmids (Table 2). The sequences of the ends of each insert were as expected for the predicted annealing position of the PCR primers (26). The PstI site in the 1.3-kb DNA-A fragment of $W$. amplissima was near the start of the rep ORF.
Hybridization of the viral inserts of pSGJA1 and pWGJA1 to weed samples. To determine the distribution of the geminiviruses cloned from Sida sp. and $W$. amplissima, digoxigenin-labeled DNA-A viral inserts of pSGJA1 and pWGJA1 were used as probes at high stringency in dot blot hybridization to the weed samples that gave hybridization signals with the geminiviral DNA probe from pBGJA. The probe from pSGJA1 was used with the samples of Sida spp. and M. lathyroides, and gave strong hybridization signals from all the Sida spp. samples. Also, this probe gave strong hybridization signals with $60 \%$ of the M. lathyroides samples (Table 1), and these were the samples that gave the 0.5-kb PCR-amplified fragment with the primer pair PBC1v2039/PCRc2. All six W. amplissima samples hybridized strongly with the probe from pWGJA1. The probe from pSGJA1 did not hybridize with DNA from the four symptomless weed samples or with pWGJA1. Likewise, the probe from pWGJA1 did not hybridize with the DNA from the four symptomless weed samples or with pSGJA1. This indicates that these two viruses, the one from Sida spp. and the one from $W$. amplissima, are widely distributed on the island and that the geminivirus from Sida spp. is also present in some M. lathyroides samples. Also,

Fig. 2. continued from previous page

101

BGMV-DR

BGMV-GA

AbMV

BDMV

TOMOV

TGMV

BGMV-BZ

PYMV

SidGMV-JA

Ma CGMV-JA

WGMV

MacGMV-DR

TLCrV

$\mathrm{PHV}$

SqLCV-E

$B C M O V$

SqLCV-R

Cons

$$
151
$$

BGMV-DR

BGMV-GA

AbMV

BDMV

TOMOV

TGMV

$B G M V-B Z$

PYMV

SidGMV-JA

Ma CGMV-JA

WGMV

MacGMV-DR

TLCrV

PHV

SqLCV-E

BCMOV

SqLCV-R

Cons
GGAGTA..CA ATATATACTA GAACCCTCAA TCTCGTGAAT TACGAGATTC GGAGTA..CA ATATATACTA GTACCCTCAA TCTCGTGAAT TATCAGATTC GGAGGT..CT TTATATACTA GAACTCTCAT TAACGGATTT G....... GGAGTT..AC TTATATACTA GAACCCTCAA TCTGGTTTCG G....... AGAGTAACTT ATATATA. . A GAACCCTCTA TAGAACTATT AATCTGGTTC GGTAG..CTC TTATATATTA GAAGTTCCTA AGGGG........... GGTG...CCA ATATATAGTA AGAAGTTCTT TAAGGATCTG TAG...... GGGGG. . AAC TTATATAGTA GAAGTTCCTA AAGGCAGAT. . ....... GGGGG.. AAC TTATATAGTA GAAGTTCCTT AAAGGCTAAT ........ GGGGG. . AAC TTATATACTA. GAAGCTCCTA AGGTAAAAC. AA........ GGTGT. . ACA ATTTATACTA GAACCCTCAA TAGAACTTTC AATCGtGTTC GGTGT.... A TAATATACTA GAACGCTCTA TAGAACTTCT AATCTCATTC GGGGA... CA ATATATACTA CAACTCTTAG TAGCACTTTA GCG...... GGTAG..CCA ATATATAGTA TATGGGAGTT ATCTAGGATC TTCGT..... GGTGT. . CCT ATATATACCT CAAGACACAT AAAGCCTCTA GGGGACACCA GGTGT..CCC ATATATACTA CAAGTCTCTT TAGGCCTCTT TAGGACACCA GGTGT...CCC ATTTATACAA CTCTCT..........GGG GAGGACACCA ggtgt..ccc ataTATActa gaaccctcta tagg.ctatt tatca.a..c

$$
\star \star \star \star
$$

ACACACGTGG .. CGgCCATC CGATATAATA TTACCGGATG GCCGCGCGCG

ACACACGTGG .. CGGCCATC CGATATAATA TTACCGGATG GCCGCCCGCG

CAACACGTGG . CGGCCATC CGCTATAATA TTACCGGATG GCCGCGCG

.AACACGTGG ..CGGCCATC CG.TATAATA TTACCGGATG GCCGCG

ATACACGTGG ...CGGCCATC CGATATAATA TTACCGGATG GCCGCG

...CACGTGG ..CGGCCATC CG.TTTAATA TTACCGGATG GCCGCG

..ACACGTGG ..CGGCCATC CGCTATAATA TTACCGGATG GCCGCG

CAACACGTG. ...CGGCCATC CGTTATAATA TTACCGGATG GCCGCG

CAACACGTGT ..CGGCCATC CGTTATAATA TTACCGGATG GCCGCGCG

. CACACGTGG ... CGGCCATC CGCTATAATA TTACCGGATG GCCGCGCG

GCACACGTGG ..CGGCCATC CGCTATAATA TTACCGGATG GCC

GCACACGTGG .. CGGCCATC CGATATAATA TTACCGGATG GCCGCG

..ACACGTGG ...CGGCCATC CGATATAATA TTACCGGATG GCCGCG

.. ACACGTGA G..GGCCATC CGTTATAATA TTACCGGATG GCCG

AGGGGCAAAA T.CGGCCATC CGCAATAATA TTACCGGATG GCCGCCCG

TGGGCAAAAT . . CGXCCATC CGAAATAATA TTACCGGATG GCCGCG

GGGGCAAAAT ..CGGCCATC CGCAATAATA TTACCGGATG GCCGC

acacacgtgg ...CGgCCATC CGataTAATA TTACCGGATG GCGCgCGCG 
the geminivirus in $M$. lathyroides, which gave a $0.55-\mathrm{kb}$ PCR fragment with primer pair PBC1v2039/PCRc2, needs to be identified.

Sequence analysis. The nucleotide sequences of parts of the common region, and the rep, $c p, \mathrm{BC} 1$, and $\mathrm{BV} 1 \mathrm{ORF}$ of cloned geminiviruses from Sida sp., $M$. lathyroides, and $W$. amplissima are listed in Table 2. serts of the DNA-A and DNA-B from Sida sp. (sample 3) and W. amplissima (sample 27) were compared to determine if these plants were infected with a bipartite geminivirus. The common regions for the putative geminivirus cloned from Sida sp. (pSGJA1, pSGJB1) for DNA-A and DNA$\mathrm{B}$, respectively, were greater than $99 \%$ identical, as were the common regions for the DNA-A and DNA-B inserts from $W$. amplissima. Therefore, both the Sida sp. and $W$. amplissima samples have a bipartite geminivirus associated with them. A comparison of the DNA-A common regions of pSGJA1 and pWGJA1 gave $61 \%$ nucleotide (nt) identity. Nucleotide comparisons of the entire common region and the sequenced parts of rep and $c p$ ORFs of the viral inserts of pSGJA1 and pMGJA3 were greater than $97 \%$ identical, which indicates that these two plant species are infected

The nucleotide sequences of the cloned viral inserts were compared with those of 7 bipartite, whitefly-transmitted geminiviruses representing the major phylogenetic clusters for the Western Hemisphere.
The common region sequences of the inwith the same virus.

These include tomato mottle geminivirus (ToMoV; GenBank no. L14460, L14461) from Florida, BGMV-GA type II from Guatemala (GenBank no. M91604, M91605), BGMV-BZ type I from Brazil (GenBank no. M88686, M88687), pepper huasteco geminivirus (PHV; GenBank no. X70418, X70419) from Mexico, potato yellow mosaic geminivirus (PYMV; GenBank no. D00940, D00941) from Venezuela, squash leaf curl geminivirus with an extended host range (SqLCV-E; GenBank no. M38132, M38133) from California, and tomato golden mosaic geminivirus (TGMV; GenBank no. K02029, K02030) from Brazil. Nucleotide sequences of the rep ORF of pWGJA2 from $W$. amplissima showed the highest nt identity $(78 \%)$ to ToMoV and less than $77 \%$ identity to the six crop-infecting geminiviruses from the Western Hemisphere. Similar comparisons for the geminivirus from Sida sp. showed $85 \%$ identity to homologous regions of PYMV and less than $77 \%$ to the other six viruses (Table 3). The common region, $c p$, and $\mathrm{BC} 1$ sequence pairwise comparisons gave similar trends.

Comparison of these sequences for the geminiviruses from Sida sp. and W. amplissima from Jamaica with sequences of geminiviruses from other weed samples collected in the Western Hemisphere indicated that these geminivirus from Jamaica were not previously reported. Pairwise comparison of the common region sequences of the geminivirus from Sida sp. and the one from $W$. amplissima with those of Macroptilium golden mosaic geminivi-

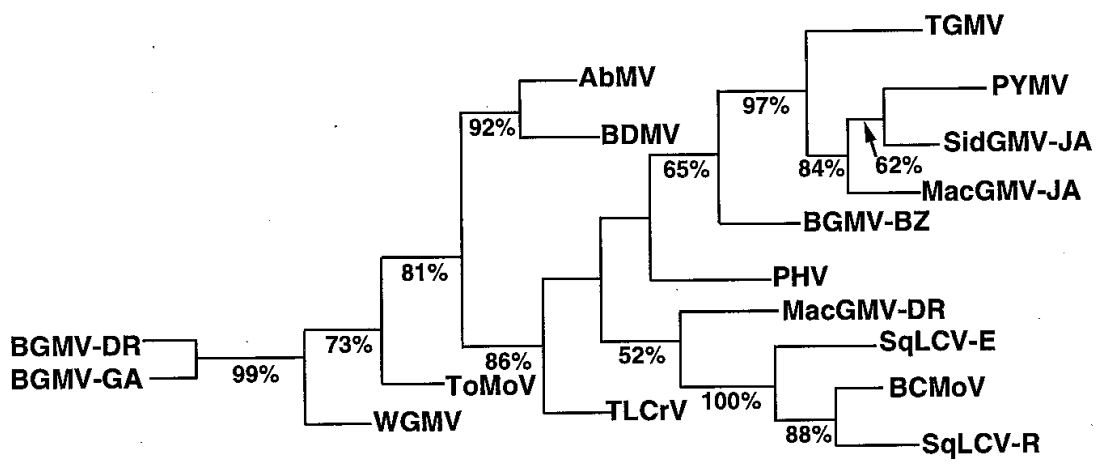

Fig. 3. Cladogram showing the interrelationship among 17 Western Hemisphere bipartite geminiviruses based on alignment of nucleotide sequence of the common region (Fig. 2). Sequences were analyzed by the PAUP program using Heuristic tree construction and branch strength was tested by construction of 100 trees using bootstrap with branch swapping. The percentages of trees with a given branch are below the horizontal lines. Vertical distances are arbitrary and horizontal distances are proportional to the number of nucleotide differences between branch nodes. BGMV-GA = bean golden mosaic geminivirus from Guatemala (M91604), BGMV-BZ = bean golden mosaic geminivirus from Brazil (M88686), BGMV-DR = bean golden mosaic geminivirus from the Dominican Republic (L01635), AbMV = Abutilon mosaic geminivirus from West Indies (X15983), BDMV = bean dwarf mosaic virus from Colombia (M88179), ToMoV = tomato mottle virus from Florida, TGMV = tomato golden mosaic geminivirus from Brazil (K02029), PYMV = potato yellow mosaic geminivirus from Venezuela (D00940), SidGMV-JA = Sida golden mosaic virus from Jamaica (U69601), WGMV = Wissadula golden mosaic virus from Jamaica ((U69603), MacGMV-DR = Macroptilium golden mosaic virus from the Dominican Republic (25), MacGMV-JA = Macroptilium golden mosaic geminivirus from Jamaica (isolate 2, U73511), $\mathrm{TLCrV}=$ tomato leaf crumple virus from Mexico (L34748), PHV = pepper huasteco virus from Mexico (X70418), SqLCV-E = squash leaf curl geminivirus from California, with extended host range (M38183), BCMoV = bean calico mosaic geminivirus (L22757), SqLCV-R = squash leaf curl geminivirus from California, with restricted host range (16). rus from the Dominican Republic (MacGMV-DR), Sida golden mosaic geminivirus from Costa Rica (SidGMV$\mathrm{CR}$ ), and Calopogonium golden mosaic geminivirus from Costa Rica (25) had nucleotide identities of $\leq 80 \%$. Thus, different geminiviruses infect these weeds in different regions of the Caribbean Basin and Central America, and none of these weed-infecting geminiviruses have been detected in a crop plant $(3,25)$.

Common region analysis. The organization of the common region is important in determining phylogenetic relationships among geminiviruses $(1,7)$. Common region alignment for the DNA-A for the three geminivirus isolates from this study and nine geminiviruses that represent the major phylogenetic clusters for Western Hemisphere geminiviruses were compared (Fig. 2). A repeat motif of 14 nucleotides GAGGGGTGTCACCA was present at approximately 15 nucleotides $3^{\prime}$ of the start of the common region for pWGJA1. Smaller repeats in this part of the common region were present in other viruses, including ToMoV and BDMV (TACTCCA), AbMV (TACTC), and PYMV (ATGTTC). This repeat motif was not present in pSGJA1 and pMGJA1. Another repeat motif is found immediately $5^{\prime}$ of the TATA box for rep ORF (7), which is the likely target for the binding of the homologous Rep protein (8). The motif for pSGJA1 and pMGJA1 is TGGGGGAAC (viral sense polarity) and corresponds to the repeat in PYMV and is distinctly different from those for other geminiviruses (7). This motif for pWGJA1 is TGGTGAC (viral sense polarity) and appears to be unique. This repeat motif for each geminivirus is also present on the complementary strand about 33 nt $3^{\prime}$ of the TATA box for rep ORF, as originally discussed by ArgüelloAstorga et al. (1). In the Western Hemisphere geminiviruses, a CACGTG motif is located immediately $5^{\prime}$ of the stem-loop motif, except for the viruses in the SqLCV cluster, which have a GGGGCAAA motif at this position (7). These motifs are not present in members of the Eastern Hemisphere whitefly-transmitted geminiviruses (7). The CACGTG motif is similar to the well-defined transcriptional cis-regulated elements in plants (1). The conserved stemloop motif, which is essential for DNA replication, was present in all three geminivirus isolates from Jamaica $(7,17)$, and only slight differences were present. The loop sequence, TAATATTAC, which contains the nicking site essential for rolling circle replication (15), was conserved in the stem-loop regions of these Jamaican isolates.

Phylogenetic analysis. The phylogenetic analyses indicate that the two geminiviruses associated with Sida spp. and W. amplissima from Jamaica are phylogenetically related to Western Hemisphere geminiviruses (7) and that they are two distinct new viruses. 
An alignment of approximately $200 \mathrm{nu}-$ cleotides of the common region (Fig. 2) of DNA-A was used to construct a cladogram (Fig. 3) of 17 whitefly-transmitted geminiviruses from the Western Hemisphere, including three new geminiviruses cloned from plant species sampled in Jamaica. The cladogram placed the Western Hemisphere geminiviruses in previously described phylogenetic groups or clusters including the BGMV type II, AbMV, and SqLCV clusters $(7,23)$. The geminivirus associated with Sida spp. and a second geminivirus infecting $M$. lathyroides (GenBank no. U75277) (28) was phylogenetically related to PYMV. Common region analysis showed that these two geminiviruses had identical conserved motifs in the common region (Fig. 2). In the common region cladogram, WGMV was not placed in a designated phylogenetic cluster (Fig. 2). A second cladogram generated from a 450 nucleotide alignment of the $\mathrm{N}$ terminus of the rep ORF of 14 whiteflytransmitted geminivirus from the Western Hemisphere, two monopartite tomato-infecting geminiviruses from the Eastern Hemisphere, and the two new geminiviruses from this study (Fig. 4) gave similar results to the common region generated cladogram.

Faria et al. (7) proposed eight phylogenetic clusters of 15 geminiviruses from the Western Hemisphere and 9 geminiviruses from the Eastern Hemisphere based on the sequence analysis of the common region, cp, rep, BV1, and BC1 ORFs. Several motifs of the common region are indicative of these clusters and include the repeat motif near the start of the common region, the repeat motif immediately upstream of the TATA box, and the GGGGCAAA motif

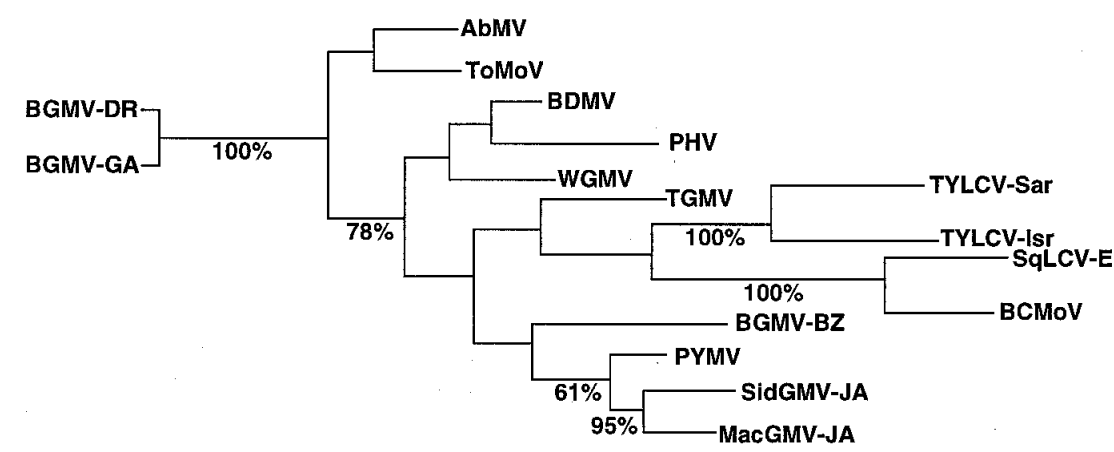

Fig. 4. Cladogram showing the interrelationships among 16 geminivirus from the Western Hemisphere based on alignment of 450 nucleotides of the N-terminal region of rep ORF. Sequences were analyzed as in Figure 3. MacGMV-JA = Macroptilium golden mosaic geminivirus from Jamaica, isolate 2 (U69159), TYLCV-Sar = tomato yellow leaf curl geminivirus from Sardinia (X61153), and TYLCV-Ipr = tomato yellow leaf curl geminivirus from Israel $(X 15656)$. BGMV-DR $=$ bean golden mosaic geminivirus from the Dominican Republic (L01635), BGMV-GA $=$ bean golden mosaic geminivirus from Guatemala (M91604), BGMV-BZ = bean golden mosaic geminivirus from Brazil (M88686), AbMV = Abutilon mosaic geminivirus from West Indies (X15983), BDMV = bean dwarf mosaic virus from Colombia (M88179), ToMoV $=$ tomato mottle virus from Florida, TGMV = tomato golden mosaic geminivirus from Brazil (K02029), PYMV = potato yellow mosaic geminivirus from Venezuela (D00940), SidGMV-JA = Sida golden mosaic virus from Jamaica (U69601), WGMV = Wissadula golden mosaic virus from Jamaica (U69603), PHV = pepper huasteco virus from Mexico (X70418), SqLCV-E = squash leaf curl geminivirus from California, with extended host range (M38183), BCMoV = bean calico mosaic geminivirus (L22757). The nucleotide sequence for the rep ORF of AbMV was adjusted as discussed previously (14). the common region that is not present in the AbMV cluster.

In conclusion, we propose that SidGMVJA be included as a new member of the PYMV cluster, and that WGMV be tentatively considered a member of a new geminivirus cluster. Neither of these viruses is associated with beans (20), tomatoes, or peppers in Jamaica (28). The common region of the bipartite geminivirus from tomatoes and peppers in Jamaica has 76 and $70 \%$ nucleotide identity to SidGMV and WGMV, respectively (M. E. Roye, M. E. Wernecke, W. A. McLaughlin, M. K. Nakhla, and D. P. Maxwell, unpublished data). Thus, the importance of weeds as alternative hosts for crop-infecting geminiviruses in Jamaica will need further investigation. From our results, it is evident that Sida spp., M. lathyroides, and W. amplissima are not reservoirs for geminiviruses important on vegetable crops in Jamaica.

\section{ACKNOWLEDGMENTS}

We thank Steve Vicen for assistance in preparation of the figures and Martha D. Maxwell for critical review of the manuscript. This research was supported in part by the University of the West Indies Postgraduate Fund (MER), by the College of Agricultural and Life Sciences, University of Wisconsin-Madison, and by a grant from USAID, as part of the USAID Bean/Cowpea CRSP Project.

\section{LITERATURE CITED}

1. Argüello-Astorga, G. R., Guevara-Gonzalez, R. G., Herrera-Estrella, L. R., and RiveraBustamante, R. F. 1994. Geminivirus replication origins have a group-specific organization of iterative elements: A model for replication. Virology 203:90-100.

2. Bos, L. 1983. Introduction to Plant Virology. Longman, London. pp. 108-124.

3. Brown, J. K. 1991. An update on the whitefly-transmitted geminiviruses in the Americas and the Caribbean Basin. FAO Plant Prot. Bull. 39:5-23.

4. Brown, J. K., and Bird, J. 1992. Whiteflytransmitted geminiviruses and associated disorders in the Americas and the Caribbean Basin. Plant Dis. 76:220-225.

5. Creamer, R., Luque-Williams, M., and Howo, M. 1996. Epidemiology and incidence of beet curly top geminivirus in naturally infected weed hosts. Plant Dis. 80:533-535.

6. Dellaporta, S. L., Wood, J., and Hicks, J. B. 1983. A plant DNA minipreparation: Version II. Plant Mol. Biol. Rep. 1(4):19-21.

7. Faria, J. C., Gilbertson, R. L., Hanson, S. F., Morales, F. J., Ahlquist, P., Loniello, A. O., and Maxwell, D. P. 1994. Bean golden mosaic geminivirus type II isolates from the Dominican Republic and Guatemala: Nucleotide sequences, infectious pseudorecombinants, and phylogenetic relationships. Phytopathology 84:321-329.

8. Fontes, E. P. B., Gladfelter, H. J., Reenah, L. S., Petty, I. T. D., and Hanley-Bowdoin, L. 1994. Geminivirus replication origins have a modal organization. Plant Cell 6:404-416.

9. Galvez, G. E., and Morales, F. J. 1989 Whitefly-transmitted viruses. Pages 379-406 in: Bean Production in the Tropics. H. F. Schanertz, and M. A. Pastor-Corrales, eds. Cent. Int. Agric. Trop., Cali, Columbia.

10. Gilbertson, R. L., Faria, J. C., Ahlquist, P., and Maxwell, D. P. 1993. Genetic diversity in geminiviruses causing bean golden mosaic 
disease: The nucleotide sequence of infectious cloned DNA components of a Brazilian isolate of bean golden mosaic geminivirus. Phytopathology 83:709-715.

11. Gilbertson, R. L., Hidayat, S. H., Martinez, R. T., Leong, S. A., Faria, J. C., Morales, F., and Maxwell, D. P. 1991. Differentiation of beaninfecting geminiviruses by nucleic acid hybridization probe and aspects of bean golden mosaic in Brazil. Plant Dis. 75:336-342.

12. Gilbertson, R. L., Hidayat, S. H., Paplomatas, E. J., Rojas, M. R., Hou, Y. M., and Maxwell, D. P. 1993. Pseudorecombination between the infectious cloned DNA components of tomato mottle and bean dwarf mosaic geminivirus. J. Gen. Virol. 74:23-32.

13. Green, S. K., and Kallo, G. 1994. Leaf curling and yellowing viruses of pepper and tomato: An overview. Asian Veg. Res. Develop. Cent. Tech. Bull. No. 21

14. Hidayat, S. H., Gilbertson, R. L., Hanson, S. F., Morales, F. J., Ahlquist, P., Russell, D. R., and Maxwell, D. P. 1993. Complete nucleotide sequences of the infectious cloned DNAs of bean dwarf mosaic geminivirus. Phytopathology 83:181-187.

15. Laufs, J., Traut, W., Heyraud, F., Matzeit, V., Rogers, S. G., Schell, J., and Gronenborn, B. 1995. In vitro cleavage and joining at the viral origin of replication by the replication initiator protein of tomato yellow leaf curl virus. Proc. Natl. Acad. Sci. USA
92:3879-3883.

16. Lazarowitz, S. G. 1991. Molecular characterization of two bipartite geminiviruses causing squash leaf curl disease: Role of viral replication and movement functions in determining host range. Virology 180:70-80.

17. Lazarowitz, S. G. 1992. Geminiviruses: Genome structure and gene function. Crit. Rev. Plant Sci. 1:327-349.

18. Lazarowitz, S. G., and Lazdins, I. B. 1991. Infectivity and complete nucleotide sequence of cloned genomic components of a bipartite squash leaf geminivirus with a broad host range. Virology 180:58-69.

19. McGlashan, D., Polston, J. E., and Bois, D. 1994. Tomato yellow leaf curl geminivirus in Jamaica. Plant Dis. 78:1219.

20. McLaughlin, W., Rojas, M. R., Nakhla, M. K., Hidayat, S. H., and Maxwell, D. P. 1994. Partial molecular characterization of bean golden mosaic virus isolates from Jamaica and Central America. Plant Dis. 78:1220.

21. Morales, F., Niessen, A., Ramirez, B., and Castano, M. 1990. Isolation and partial characterization of a geminivirus causing bean dwarf mosaic. Phytopathology 80:96-101.

22. Nakhla, M. K., Maxwell, D. P., Martinez, R. T., Carvalho, M. G., and Glibertson, R. L. 1994. Widespread occurrence of the Eastern Mediterranean strain of tomato yellow leaf curl geminivirus in tomatoes in the Dominican Republic. Plant Dis. 78:926.
23. Padidam, M., Beachy, R. N., and Fauquet, C. M. 1995. Classification and identification of geminiviruses using sequence comparisons. J. Gen. Virol. 76:249-263.

24. Pierre, R. E. 1974. Observations on the golden mosaic symptoms of beans (Phaseolus vulgaris L.) in Jamaica. Pages 55-59 in: J. Bird and K. Maramorosch, eds. Tropical Diseases in Legumes. Academic Press, New York.

25. Rojas, M. R. 1992. Detection and characterization of whitefly-transmitted geminiviruses by the use of polymerase chain reaction. M.S thesis. University of Wisconsin-Madison.

26. Rojas, M. R., Gilbertson, R. L., Russell, D R., and Maxwell, D. P. 1993. Use of degenerate primers in the polymerase chain reaction to detect whitefly-transmitted geminiviruses. Plant Dis. 77:340-347.

27. Rojas, M. R., Karkashian, J. P., and Maxwell, D. P. 1992. Characterization of Geminiviruses Infecting Bean and Calopogonium sp. in Costa Rica. Ann. Rep. Bean Improv. Coop. 35:150151.

28. Roye, M. E. 1997. Genetic diversity and phylogeny of whitefly-transmitted geminiviruses from Jamaica. Ph.D. thesis. University of the West Indies, Mona.

29. Sambrook, J., Fritsch, E. F., and Maniatis, T. 1989. Molecular Cloning: A Laboratory Manual. 2nd ed. Cold Spring Habor Laboratory, Cold Spring Habor, New York. 